\title{
Immune System Dysfunction in the Elderly
}

\section{EDUARDO FUENTES ${ }^{1,2}$, MANUEL FUENTES ${ }^{1}$, MARCELO ALARCÓN ${ }^{1}$ and IVÁN PALOMO ${ }^{1}$}

\author{
${ }^{1}$ Platelet Research Laboratory, Department of Clinical Biochemistry and Immunohematology, \\ Faculty of Health Sciences, Interdisciplinary Excellence Research Program on Healthy Aging/ \\ PIEI-ES, Universidad de Talca, Postal Code 3460000, Casilla 747, Talca, Chile \\ ${ }^{2}$ Núcleo Científico Multidisciplinario, Universidad de Talca, Postal Code 3460000, Casilla 747, Talca, Chile
}

Manuscript received on August 2, 2016; accepted for publication on December 29, 2016

\begin{abstract}
Human aging is characterized by both physical and physiological frailty that profoundly affects the immune system. In this context aging is associated with declines in adaptive and innate immunity established as immunosenescence. Immunosenescence is a new concept that reflects the age-associated restructuring changes of innate and adaptive immune functions. Thus elderly individuals usually present chronic lowlevel inflammation, higher infection rates and chronic diseases. A study of alterations in the immune system during aging could provide a potentially useful biomarker for the evaluation of immune senescence treatment. The immune system is the result of the interplay between innate and adaptive immunity, yet the impact of aging on this function is unclear. In this article the function of the immune system during aging is explored.
\end{abstract}

Key words: aging, immunosenescence, adaptive immunity, innate immunity, inflammation.

\section{INTRODUCTION}

Human aging is characterized by both physical and physiological frailty. With progressive age, the immune system and the propensity for abnormal immunity change fundamentally (Weyand et al. 2014). Aging is associated with declines in adaptive and innate immunity (Lutz and Quinn 2012, Golomb et al. 2015, Wong and Goldstein 2013). Infections, cancer and autoimmune diseases occur more frequently in the elderly, and although many factors contribute to this, the age-related remodeling of the immune system, termed immunosenescence,

Correspondence to: Eduardo Fuentes

E-mail: edfuentes@utalca.cl plays a major role (Bueno et al. 2014, Mocchegiani et al. 2009, Sharma et al. 2014).

Immunosenescence involves age-associated restructuring changes of innate and adaptive immune functions (Baeza et al. 2011, Dace and Apte 2008). Immunosenescence describing alterations including the decline of immune responses with age is comprised of inappropriate elevations, decreases, and dysregulated immune responses, leading to more severe consequences of bacterial and viral infections and reduced responses to vaccination (Montgomery and Shaw 2015). Elderly individuals usually present chronic low level inflammation, likely as the consequence of continued exposure to antigens combined with poor 
immune function, increases in the production of pro-inflammatory cytokines by effector memory and senescent $\mathrm{T}$ cells and macrophages (Campos et al. 2014). In addition, there may be disease impairment through a compromised adaptive immune response due to accelerated aging of the immune system in patients with an advanced clinical status (Moro-Garcia et al. 2014).

The immune system is the result of interplay between innate and adaptive immunity, yet the impact of aging on this function is unclear. In this article the function of the immune system during aging is explored.

\section{IMMUNOSENESCENCE}

Aging is associated with a decline in multiple areas of immune function (Burns and Goodwin 1997). Aging is associated with a sort of paradox: a state of increased autoimmunity and inflammation coexistent with a state of immunodeficiency (Sardi et al. 2011). Immunosenescence is a new concept that reflects the immunological changes associated with age. (Boraschi and Italiani 2014, Fulop et al. 2014, Poland et al. 2014). There are three theories that explain the phenomenon of immunosenescence:

\section{AUTOIMMUNITY THEORY}

The autoimmune theory of aging was first introduced by Walford (1969). According to this theory, the immune system tends to lose efficiency and experiences widespread dysfunction, evidenced by autoimmunity (immune reactions against one's own body proteins) (Diggs 2008). Two age- related processes cause autoimmune diseases: (i) different rates of senescent cell accumulation in the immune system and target tissue/organ and (Pietilä et al. 2015) heterogeneous accumulation of senescent cells in tissues/organs. Separately or combined, these two processes are at the base of autoimmune diseases (Manestar-Blazic and Volf 2009). The production of autoantibodies has been hypothesized to be secondary to thymus involution with a decline of naïve $\mathrm{T}$ cells and the accumulation of clonal $\mathrm{T}$ cells with activation due to "neoantigens" during the aging process (Prelog 2006). Indeed, increased CD5+ B lymphocytes in the elderly population play a key role as producers of autoantibodies that lead to an imbalance of the mechanism controlling the immune response against self antigens (Bulati et al. 2011, Weksler 2000).

\section{IMMUNODEFICIENCY THEORY}

With advancing age the body is unable to defend itself from pathogens and results in a detrimental harm (van Deursen 2014, Childs et al. 2014).

Clinical evidence indicates that with advancing age, immune responses against recall antigens may still be conserved, but the ability to mount primary immune responses against novel antigens declines significantly. The impaired ability to mount immune responses to new antigens may result in a high susceptibility to infectious diseases (Fagnoni et al. 2000, Ahmed and Gray 1996). The immune responses to novel antigens rely on the availability of naive T cells (Fagnoni et al. 2000). Together with the age-related thymic involution, and the consequent age-related decrease of thymic output of naive CD8+ T-cell reservoir, this situation leaves the body practically devoid of virgin T cells, and thus likely more prone to a variety of infectious and non infectious diseases (Franceschi et al. 2000, Fagnoni et al. 2000).

\section{DEREGULATION THEORY}

Ageing is associated with various changes in immune parameters, therefore many authors have postulated that these age-related diseases could be explained, at least in part, by an overall deregulation in the immune system response (McElhaney and Effros 2009, Franceschi et al. 2007). This is supported by an age-associated disruption to the balance of alternatively expressed isoforms for 
selected genes, suggesting that a modification of the mRNA processing may be a feature of human aging (Harries et al. 2011). The observed down regulation of toll-like receptors (TLRs) and nodlike receptors (NLRs) during the aging process may contribute to the lack of effective recognition of invading pathogens or the commensal flora. This effect results in aberrant secondary immune cell activation and could significantly contribute to morbidity and mortality at an advanced age (Rosenstiel et al. 2008, Montoya-Ortiz 2013).

\section{EFFECTS OF AGING ON THE IMMUNE SYSTEM}

Response mechanisms associated with the immune system are divided into innate and adaptive immunity (Dunkelberger and Song 2010, Iwasaki and Medzhitov 2015). The first relates to anatomical and biochemical barriers, unspecific cellular responses that are mediated by monocytes, natural killer (NK) and dendritic cells (Vesely et al. 2011). The second relates to the fact that the response to specific antigens is mediated by $\mathrm{B}$ and $\mathrm{T}$ lymphocytes (Denson 2013). Both are involved in immune senescence, where the adaptive response is affected the most in this process (Franceschi et al. 2000).

\section{INNATE IMMUNITY}

The innate immune system is the first line of host defense against pathogens. We will describe the effect of aging on the function of innate immunity (Figure 1).

\section{SKIN AND MUCOUS}

These are the first line of defense of our body against pathogens, with age the replacement of skin cells decreases, sweat production is reduced, changes at the structural level of epithelial cells are produced, depletion of Langerhans and melanocyte cells occurs and subcutaneous tissue atrophy (Kottner et al. 2013, Campisi and d'Adda di Fagagna 2007, Chilosi et al. 2014).

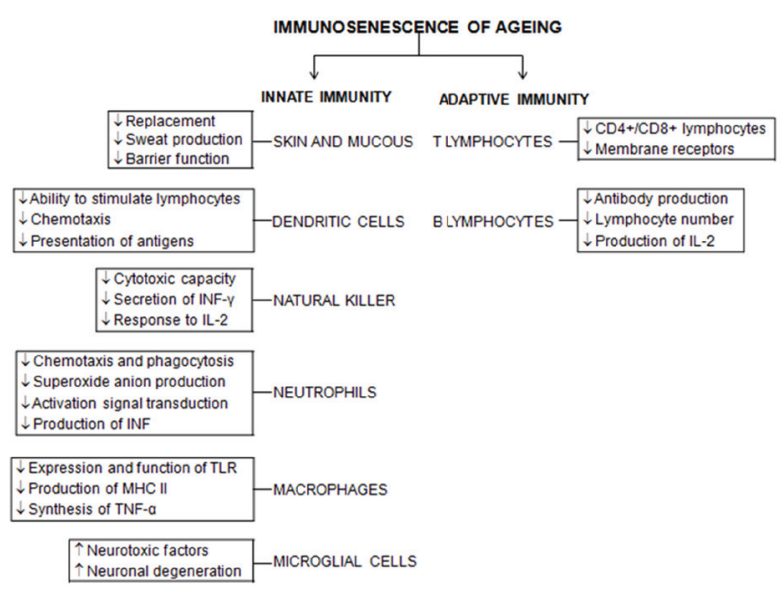

Figure 1 - Schematic representation of the main cells and their alterations involved in immunosenescence of ageing. INF: interferon, IL: interleukin, TLR: toll like receptor, MHC: major histocompatibility complex, TNF: tumor necrosis factor.

In skin, aging is associated with overall epidermal thinning, decreased barrier function, pro-inflammatory state and gradual deterioration of the epidermal immune response (Kinn et al. 2015). The mucus membranes of hair cells, which play an important role in removing pathogens, are reduced in quantity and movement, as well as presenting ultra structural changes (Kim et al. 2007). Immunoglobulin (Ig) A, the main constituent in secretions, levels increase up to 60 years old and thereafter a significant reduction in levels begins (Jafarzadeh et al. 2010, Smith et al. 1987, Ebersole and Steffen 1989). Therefore, structural and physiologic changes occur as a consequence of intrinsic aging combined with the environment can produce a marked susceptibility to dermatologic disorders in the elderly. For example, immunologic senescence in the elderly also sets the stage for potential reactivation of the Varicella zoster virus, in which initial dermatologic involvement expands into the major sensory ganglia (Farage et al. 2009, Kim et al. 2015).

\section{DENDRITIC CELLS}

Dendritic cells (DC) (Rainham et al. 2012) are responsible for the first recognition of pathogens, 
antigen processing and regulation of $\mathrm{T}$ and $\mathrm{B}$ lymphocytes and NK. Thus DC are a bridge between innate and adaptive immunity and with age a group of them can decrease such as the Langerhans cells in skin and plasmocytes (Agrawal and Gupta 2011). Aged DC exhibited profound signs of mitochondrial dysfunction, illustrated by lower $\Delta \psi \mathrm{m}$, reduced ATP turnover and coupling efficiency, decreased baseline oxidative phosphorylation, and greater proton leak and reactive oxygen species (ROS) production (Chougnet et al. 2015). Therefore, DC in aging appears to be functionally impaired with regard to the response to uptake of antigens, phagocytosis of apoptotic cells and migration (Gupta 2014).

Other altered DC elements during aging are associated with the function of TLR (Inappropriate persistence of TLR activation in specific systems), in addition to the antigen processing and cell migration, which is associated with an alteration of phosphoinositide 3 kinase pathway (Panda et al. 2010, Agrawal et al. 2007, Shaw et al. 2011). Also, a decrease in interleukin (IL)-15 interferon alpha (INF- $\alpha$ ) levels and tumor necrosis factoralpha (TNF- $\alpha$ ) has been seen (Moretto et al. 2008, Stout-Delgado et al. 2008).

The DC from older mice have a poor ability to stimulate a $\mathrm{CD} 8+\mathrm{T}$ cell-mediated cytotoxic response (Zacca et al. 2015). Impaired influenzaspecific CD8 $+\mathrm{T}$ cell response in older adults is associated with a reduced TNF- $\alpha$ production and lower DC maturation. Therefore the production of TNF- $\alpha$ is a determining factor in the DC-mediated CD8+ $\mathrm{T}$ cell response against influenza (Liu et al. 2012). In addition, a comparison of the antigenpresenting capacity of aged plasmacytoid dendritic cell (PDC) with young PDC revealed that PDC from aged subjects displays reduced capacity to induce proliferation and IFN- $\gamma$ secretion in CD4+ and CD8+ T cells as compared with PDC from young subjects (Sridharan et al. 2011, Prakash et al. 2013).

\section{NATURAL KILLERS}

The NK cells are a key component of innate immunity involved not only in the elimination of virus-infected or tumor cells but also in the regulation of the immune response by producing cytokines and chemokines that can activate other cellular components of innate and adaptive immunity (Gayoso et al. 2011, Camous et al. 2012, Vivier et al. 2008).

Aged nonhematopoietic environment is an important contributor to the impaired maturation and function of NK cells in aging (Shehata et al. 2015). Changes in NK cell biology that accompany human ageing are: (i) the increased reactivation rates of latent Mycobacterium tuberculosis, (Pietilä et al. 2015) a slower resolution of inflammatory responses and (ii) the increased incidence of bacterial and fungal infection are attributable in part to an age-associated decline in NK cell function (Hazeldine and Lord 2013, Mariani et al. 2002, Rajagopalan and Long 2012, Borrego et al. 1999).

Human NK cells can be subdivided into two populations based on the density of cell surface CD56 antigen. The great majority (approximately $90 \%$ ) of NK cells express CD56 at low levels (the CD56dim phenotype), whereas a small NK cell subset (approximately 10\%) exhibits approximately fivefold greater density of surface CD56 (CD56bright). Under normal conditions, exposure to exogenous IL-2 induces tenfold greater proliferation of CD56bright cells compared to CD56dim lymphocytes (Baume et al. 1992). However, during aging there is a redistribution of NK cell subsets as shown by a decrease of CD56bright cells and an increase of CD56-CD16+ NK cells (Solana et al. 2014, Krishnaraj 1997). In this way, the amount of IFN- $\gamma$ secreted by NK cells from the elderly was only 25 percent of that released by the cells from younger samples (Krishnaraj 1997). Even, a decrease in the expression of activating receptors (NKp30 and NKp46) was observed in 
NK cells in elderly individuals (Almeida-Oliveira et al. 2011) (Hayhoe et al. 2010, Hazeldine and Lord 2013). Conversely, aging-related functional NK cell deficiency was completely reversed by injecting soluble IL-15/IL-15R $\alpha$ complexes (Chiu et al. 2013, Elpek et al. 2010).

\section{NEUTROPHILS}

Neutrophils are recruited to the infection site by cytokine and chemokine mainly by IL-1 and IL-8 (Sica et al. 1990, Kunkel et al. 1991). When involved in phagocytosis, the generation of ROS, degranulation releasing enzymes and antimicrobial peptides and neutrophil extracellular traps (NETs), in order to eliminate the pathogen from our organism (Zawrotniak and Rapala-Kozik 2013, Borregaard 2010). In addition, they facilitate the maturation and migration of DC that will initiate the adaptive immune response (Solana et al. 2012).

Neutrophil has a short half-life, presenting a spontaneous apoptosis, which is augmented by pro-inflammatory cytokines such as INF-1 and stimulating factor granulocyte-monocyte colony of (G-CSF), this effect is diminished as we age since there is an alteration in the activation of the JakSTAT (Fortin et al. 2007, Kojima et al. 2013). In addition, the marked decline in TCRL(n) repertoire diversity in old age identifies a novel mechanism of immunosenescence in neutrophils (Fuchs et al. 2012).

Neutrophil migration into the lungs is impaired in aged mice $24 \mathrm{~h}$ after intratracheal infection despite elevated chemokine levels, suggesting that immunosenescence is impairing neutrophil migration (Chen et al. 2014). Inaccurate migration was causally associated with increased constitutive phosphoinositide 3-kinase (PI3K) signaling; untreated neutrophils from old donors demonstrated significant PI3K activation compared with cells from young donors. PI3K-blocking strategies, specifically inhibition of PI3K $\gamma$ or PI $3 \mathrm{~K} \delta$, restored neutrophil migratory accuracy, whereas SHIP1 inhibition worsened migratory flaws (Sapey et al. 2014). In addition, phagocytosis also altered, for example a reduction in receptor expression is observed CD16 (Fulop et al. 1985, Butcher et al. 2000).

Recently an alteration in pathogen destruction mechanism mediated by neutrophil extracellular traps (NETs) was demonstrated, which it is one of the results of increased infections in older individuals (Brinkmann and Zychlinsky 2007). Besides these neutrophils have lower activation against TNF- $\alpha$, interleukin (IL)-8 and lipopolysaccharide (LPS), with a consequent reduction in production of ROS (Hazeldine et al. 2014, Summers et al. 2010).

\section{MACROPHAGES}

Macrophages main function is involved in phagocytosis synthesize pro-inflammatory cytokines TNF- $\alpha$, IL-1, IL- 6 and IL-8, in addition to processing and presenting antigens to T cells and participating in adaptive immunity (Weiskopf et al. 2009, Shi and Pamer 2011). Activated macrophages are now broadly classified into two subsets; proinflammatory (M1) or an anti-inflammatory (M2) phenotype. Classical activation is induced by IFN- $\gamma$ and LPS and produces cells with a M1 phenotype, and alternative activation is induced by IL-4 and IL-13 and produces M2 cells. M1 and M2 cells differentially express a range of chemokines and also have distinct metabolic programmes (Fuentes et al. 2013). In this context, expression of both M1 and M2 markers was reduced in adherent splenocytes from old mice, indicating that ageing did not cause a skew towards M1 or M2 phenotype (Mahbub et al. 2012). The reduced expression of M2 markers may be, in part, due to lower numbers of splenic F4/80+IL-4R+ cells in aged mice compared with young (Mahbub et al. 2012).

Telomeres shorten with age in macrophages leading to a decreased GM-CSF but not M-CSFdependent proliferation of these cells as a result of decreased phosphorylation of STAT5. Macro- 
phages from aged mice showed increased susceptibility to oxidants and an accumulation of intracellular reactive oxygen species (Sebastian et al. 2009, Guayerbas et al. 2002). Also, macrophages from older animals lost the capacity to respond to pharmacological $(10(-3) \mathrm{M})$ concentrations of norepinephrine (NE). The lower capacity of response to NE by macrophages from older animals possibly contributes to immunosenescence (Ortega et al. 2000). The changes observed in the macrophages (stronger generation of nitric oxide (NO) and ROS) isolated from the elderly indicate that these cells could contribute to the development of metabolic disorders like atherosclerosis and diabetes (Suchy et al. 2014).

During aging macrophages considerably reduce the production of cytokines such as TNF- $\alpha$ and IL-6 (van Duin et al. 2007b, Davalos et al. 2010), and decrease in B7 receptor expression, which allows the activation of $\mathrm{T}$ cell (van Duin et al. 2007a). This also shows a reduction in the expression of major histocompatibility complex (MHC) class II gene IA complex product and the levels of intracellular IAbeta protein and mRNA (Villanueva et al. 1990, Herrero et al. 2002, 2001). Meanwhile, activated macrophages which function as antigen presenting cells were decreased in aged rats (Kizaki et al. 2002).

Significant up regulation of miR-101b and miR-26b effectively prevented LPS-induced excessive expression of cyclooxygenase (Odden et al. 2011)-2 in young mice. Meanwhile, histone deacetylase suppressed the expression of miR$101 \mathrm{~b}$ and miR-26b in the LPS-treated macrophages of aged mice and contributed to the aging process (Liu et al. 2015).

The miR-146a, which negatively regulated the expression of IL-1 $\beta$ and IL-6, was highly expressed in aged mice. The dysregulated expression of miR146a results in the age-associated dysfunction of macrophages, and miR-146a may be a good target for the treatment of age-related inflammatory diseases (Jiang et al. 2012). In addition, autophagy modulation may prevent excess inflammation and preserve macrophage function during aging, improving immune responses and reducing the morbidity and mortality associated with inflammaging (Stranks et al. 2015).

\section{MICROGLIAL CELLS}

Microglia reside in the central nervous system (CNS), comprising of approximately $12 \%$ of the brain, and serve as the brain's immune defense. Microglia cells are unique from neurons, oligodendrocytes, and astrocytes in that they are not derived from the neuroectoderm (Dheen et al. 2007). Microglia cells play an important role in CNS homeostasis during development, adulthood and ageing. Microglia function is tightly regulated by the CNS microenvironment, and increasing evidence suggests that disturbances, such as neurodegeneration and ageing, can have profound consequences for microglial phenotype and function (Perry and Teeling 2013). Accumulating evidence points to activated microglia as a chronic source of multiple neurotoxic factors, including TNF- $\alpha$, NO, IL1- $\beta$, and ROS, driving progressive neuron damage, particularly in the case of Parkinson's Disease (Lull and Block 2010, Graeber et al. 2011).

Under physiological conditions, the number and function of microglia is tightly controlled by the local microenvironment. In response to neurodegeneration and the accumulation of abnormally folded proteins, however, microglia multiply and adopt an activated state - a process referred to as priming. Priming makes the microglia susceptible to a secondary inflammatory stimulus, which can then trigger an exaggerated inflammatory response. The secondary stimulus can arise within the CNS, but in elderly individuals, the secondary stimulus most commonly arises from a systemic disease with an inflammatory component (Perry and Holmes 2014). The cause of this amplified microglial activation may be 
related to impairments in several key regulatory systems with age that make it more difficult to resolve microglial activation (Norden and Godbout 2013). Thus, microglias of the aged brain are termed primed with a higher expression of MHC II and pro-inflammatory cytokines including IL-1 $\beta$. In addition, there are clear age associated deficits in memory and learning and neuronal plasticity (Henry et al. 2009).

\section{ADAPTIVE IMMUNITY}

The adaptive immune system depends on the generation of a diverse repertoire of antigen receptors on $\mathrm{T}$ and $\mathrm{B}$ lymphocytes and subsequent activation and clonal expansion. The induction of adaptive immunity, not only depends on the recognition of the particular antigen receptor, but is also based on essential signals that are delivered by the innate immune system (Schenten and Medzhitov 2011). A well-described age-related alteration of the immune system is the decrease of de novo generation of $\mathrm{T}$ and $\mathrm{B}$ cells (Stervbo et al. 2015). We will describe the effect of aging on the function of B and T lymphocytes (Figure 1).

\section{B LYMPHOCYTES}

The primary function of B lymphocytes is the production of antibodies in response to infection from a pathogen (Tedder et al. 1997, Gitlin and Nussenzweig 2015). The B cell arm of adaptive immunity undergoes significant modifications with age. Elderly people are characterized by impaired $\mathrm{B}$ cell responses and defective antibody production reflected in a reduced ability to effectively respond against viruses and bacteria (Buffa et al. 2013, Ademokun et al. 2010, Visentini et al. 2011). Thus, the formation of antibodies in response to vaccination against hepatitis $B$ virus infection was significantly reduced for donors with a mean age of 61 years compared with a group with a mean age of 33 years (Rosenberg et al. 2013).
Immunosenescence is characterized by the impairment of humoral immunity with changes in the memory/naive B cell compartment (Martorana et al. 2014). The increase of memory B cells $(\operatorname{IgG}(+)$ $\operatorname{IgD}(-) \mathrm{CD} 27(-)$, double negative, $\mathrm{DN})$ population in the elderly, in which there is also a typical inflammatory micro-environment. In the elderly, naïve/memory B cell populations present a different expression of the studied receptors that could be discussed in terms of "inflamm-aging”. In particular $\operatorname{IgG}(+) \operatorname{IgD}(-) C D 27(-)$ DN B cells show a tissue trafficking phenotype and they can be stimulated to produce granzyme B (Bulati et al. 2014). Double negative (IgG+IgD-CD27-) B cells are increased in a cohort of moderate-severe Alzheimer's disease patients and show a pro-inflammatory trafficking receptor phenotype (Bulati et al. 2015).

Immunosenescence in the B-lineage is not irreversible and depletion of the long-lived B cells in old mice rejuvenates the B-lineage and enhances immune competence (Keren et al. 2011). Naïve B cells from young donors need a sufficiently strong stimulus to be activated "in vitro", while naïve B cells from old subjects are able to produce IL-10 and TNF- $\alpha$ when stimulated "physiologically" $(\alpha-$ CD40/IL-4), suggesting that these cells might play a role in the control of the immuno-inflammatory environment in the elderly (Buffa et al. 2011).

Plasma cells are terminally differentiated elements derived from B lymphocytes. Plasma cell numbers decrease in the bone marrow of old patients (Pritz et al. 2015). This reduction of clonal expansion of plasma cells results in a low affinity of antibodies to antigens (Dunn-Walters et al. 2003, Effros et al. 2005, Johnson and Cambier 2004).

\section{T LYMPHOCYTES}

These can be divided into CD4 and CD8 recognizing antigens in the context of MHC (Lenardo et al. 1999, Arsenio et al. 2014, King et al. 2008). Aging is associated with an increased susceptibility to 
infection and disease. It is also associated with reduced functionality and altered distribution of the immune cells, especially T cells (Vasudev et al. 2014, Tesar et al. 2006).

Age-related regression of the thymus is associated with a decline in naïve $\mathrm{T}$ cell output (MoroGarcia et al. 2012, Chou and Effros 2013, AlonsoArias et al. 2011). This is thought to contribute to the reduction in $\mathrm{T}$ cell diversity seen in older individuals and linked with increased susceptibility to infection, autoimmune disease and cancer (Palmer 2013). Oxidative stress and chronic antigenic load increases with age reduced lymphocyte susceptibility to damage-induced cell death and enhances proinflammatory status leading to increased activation induced cell death (Sikora 2015).

Altered lymphocyte potassium channel inhibitory patterns, regulators of calcium influx kinetics, might contribute to the development of age-related changes of $\mathrm{T}$ cell function (Kollar et al. 2015). It also presents a reduction of membrane receptors such as CD28 (important in lymphocyte activation) and CD27 (limited proliferative capacity by T lymphocytes) (Vallejo 2005, Parish et al. 2009, Warrington et al. 2003, FerrandoMartinez et al. 2011, Cao et al. 2010). In addition to a decrease in intracellular calcium levels and alterations in the signal transduction pathways NF $\mathrm{kB}$ and MAPK have been observed (Deruy et al. 2014, Garcia and Miller 2002, Jing and Lee 2014). Recently decreased miR-181a has been associated with age, this controls lymphocyte activation via their $\mathrm{T}$ cell receptor this decline results in poor cell activation and also recognizing autoantigens ( $\mathrm{Li}$ et al. 2007, 2012).

Endogenous p53 isoforms $\Delta 133 \mathrm{p} 53$ and p53 $\beta$ are physiological regulators of proliferation and senescence in human $\mathrm{T}$ lymphocytes in vivo. Conversely, $\Delta 133 \mathrm{p} 53$ knockdown or $\mathrm{p} 53 \beta$ overexpression in $\mathrm{CD} 8+\mathrm{CD} 28+$ cells inhibited cell proliferation and induced senescence (Mondal et al. 2013). CD4 T cell lymphopenia is an important $T$ cell defect associated to ageing (Martinet et al. 2014). Meanwhile, menin binding at Bach2 locus and Bach 2 expression are decreased in the senescent CD4 T cells. T cell-specific Menin deficiency results in the premature senescence of CD4 T cells, which is accompanied by the senescence-associated secretory phenotype after antigenic stimulation and dysregulated cytokine production (Kuwahara et al. 2014). In aging individuals, reduced CD8+ T-cell priming capacity in vitro was further associated with poor primary immune responsiveness in vivo. This immune deficit likely arises as a consequence of intrinsic cellular defects and a reduction in the size of the naïve CD8+ T-cell pool (Briceno et al. 2015). Immunosenescence appeared to be pronounced in patients with breast cancer, with senescent CD8+ T-cells playing a role (Onyema et al. 2015).

Changes in the TH17/Treg ratios (TH17 cells were significantly increased in older individuals whereas Tregs were reduced) in combination with altered cytokine expression during aging may contribute to an imbalance between the proinflammatory and the anti-inflammatory immune response. This indicates a higher susceptibility to develop inflammatory diseases with increasing age (Schmitt et al. 2013).

\section{BIOMARKERS OF SENESCENCE}

Senescence biomarkers should be applicable for use in vivo due to the role of increased senescence in age-related diseases (Bernardes de Jesus and Blasco 2012). The CD8+CD28-CD27+ cell and antithymocyte globulin (ATG)-induced CD4(+) T cell lymphopenia are used as a biological marker of accelerated immunosenescence ( $\mathrm{Ng}$ et al. 2015, Crepin et al. 2015).

It is believed that senescence is activated in an intermediate state where the tumor started but did not reach full malignancy, which usually coincides with the normal function of the major barriers p53 and p16. (Collado et al. 2005). Moreover, aged heart patients presented an increase in 
senescent cells (positive for p16, p21, p53, and presenting short telomeres), which, together with the aforementioned characteristics, resulted in the development of cardiac failure (Chimenti et al. 2003, Torella et al. 2004).

A number of senescence markers have been used to identify senescent cells. For example, growth arrest, although a necessary condition for senescence, is not sufficient to define the state many cells in vivo are terminally differentiated or quiescent. p16 $6^{\mathrm{INK} 4 \mathrm{a}}$ is highly correlated with senescence and age, and lamin B1 declines in mouse tissues with persistent senescent cells and therefore may be useful in both research and clinical applications, and senescence-associated beta-galactosidase (SA- $\beta$ gal), the most widely used senescence marker (Campisi and d'Adda di Fagagna 2007, Freund et al. 2012). Moreover, senescent cells secrete interleukins, inflammatory cytokines, and growth factors that can affect surrounding cells. Thus plasminogen activator inhibitor-1 (PAI)-1, IL-1, IL-6, IL-8 and colonystimulating factors (CSFs, including GM-CSF and G-CSF) are candidate biomarkers of senescence because they are soluble factors overexpressed by senescent cells (Coppe et al. 2010, Binet et al. 2009).

\section{CONCLUSIONS}

During aging, immune senescence is a process that affects the entire immune system. It corresponds to multiple alterations of the immune system, which results in a higher rate of infections and increase of diseases. In addition, alterations of the immune system during aging could provide a potentially useful biomarker for the evaluation of immune senescence treatment.

\section{ACKNOWLEDGMENTS}

Interdisciplinary Excellence Research Program on Healthy Aging (PIEI-ES) funded this work.
Also Eduardo Fuentes thanks Fondo Nacional de Desarrollo Científico y Tecnológico (FONDECYT) $\mathrm{N}^{\circ} 11140142$.

\section{REFERENCES}

ADEMOKUN A, WU YC AND DUNN-WALTERS D. 2010. The ageing $\mathrm{B}$ cell population: composition and function. Biogerontology 11(2): 125-137.

AGRAWAL A, AGRAWAL S, CAO JN, SU H, OSANN K AND GUPTA S. 2007. Altered innate immune functioning of dendritic cells in elderly humans: a role of phosphoinositide 3-kinase-signaling pathway. J Immunol 178(11): 6912-6922.

AGRAWAL A AND GUPTA S. 2011. Impact of aging on dendritic cell functions in humans. Ageing Res Rev 10(3): 336-345.

AHMED R AND GRAY D. 1996. Immunological memory and protective immunity: understanding their relation. Science 272(5258): 54-60.

ALMEIDA-OLIVEIRA A ET AL. 2011. Age-related changes in natural killer cell receptors from childhood through old age. Hum Immunol 72(4): 319-329.

ALONSO-ARIAS R, MORO-GARCIA MA, LOPEZVAZQUEZ A, RODRIGO L, BALTAR J, GARCIA FM, JAURRIETA JJ AND LOPEZ-LARREA C. 2011. NKG2D expression in CD4+ T lymphocytes as a marker of senescence in the aged immune system. Age 33(4): 591605.

ARSENIO J, KAKARADOV B, METZ PJ, KIM SH, YEO GW AND CHANG JT. 2014. Early specification of CD8+ $\mathrm{T}$ lymphocyte fates during adaptive immunity revealed by single-cell gene-expression analyses. Nat Immunol 15(4): 365-372.

BAEZA I, DE CASTRO NM, ARRANZ L, FDEZTRESGUERRES J AND DE LA FUENTE M. 2011. Ovariectomy causes immunosenescence and oxi-inflammageing in peritoneal leukocytes of aged female mice similar to that in aged males. Biogerontology 12(3): 227-238.

BAUME DM, ROBERTSON MJ, LEVINE H, MANLEY TJ, SCHOW PW AND RITZ J. 1992. Differential responses to interleukin 2 define functionally distinct subsets of human natural killer cells. Eur J Immunol 22(1): 1-6.

BERNARDES DE JESUS B AND BLASCO MA. 2012. Assessing cell and organ senescence biomarkers. Circ Res 111(1): 97-109.

BINET R ET AL. 2009. WNT16B is a new marker of cellular senescence that regulates p53 activity and the phosphoinositide 3-kinase/AKT pathway. Cancer Res 69(24): 9183-9191.

BORASCHI D AND ITALIANI P. 2014. Immunosenescence and vaccine failure in the elderly: strategies for improving response. Immunol Lett 162(1): 346-353. 
BORREGAARD N. 2010. Neutrophils, from marrow to microbes. Immunity 33(5): 657-670.

BORREGO F, ALONSO MC, GALIANI MD, CARRACEDO J, RAMIREZ R, OSTOS B, PENA J AND SOLANA R. 1999. NK phenotypic markers and IL2 response in NK cells from elderly people. Exp Gerontol 34(2): 253-265.

BRICENO O ET AL. 2015. Reduced naive CD8 T-cell priming efficacy in elderly adults. Aging Cell 15(1):14-21.

BRINKMANN V AND ZYCHLINSKY A. 2007. Beneficial suicide: why neutrophils die to make NETs. Nat Rev Microbiol 5(8): 577-582.

BUENO V, SANT'ANNA OA AND LORD JM. 2014. Ageing and myeloid-derived suppressor cells: possible involvement in immunosenescence and age-related disease. Age 36(6): 9729.

BUFFA S, BULATI M, PELLICANO M, DUNNWALTERS DK, WU YC, CANDORE G, VITELLO S, CARUSO C AND COLONNA-ROMANO G. 2011. B cell immunosenescence: different features of naive and memory B cells in elderly. Biogerontology 12(5): 473-483.

BUFFA S, PELLICANO M, BULATI M, MARTORANA A, GOLDECK D, CARUSO C, PAWELEC G AND COLONNA-ROMANO G. 2013. A novel B cell population revealed by a CD38/CD24 gating strategy: CD38(-)CD24 (-) B cells in centenarian offspring and elderly people. Age 35(5): 2009-2024.

BULATI M, BUFFA S, CANDORE G, CARUSO C, DUNN-WALTERS DK, PELLICANO M, WU YC AND COLONNA ROMANO G. 2011. B cells and immunosenescence: a focus on $\operatorname{IgG}+\operatorname{IgD}-\mathrm{CD} 27-(\mathrm{DN}) \mathrm{B}$ cells in aged humans. Ageing Res Rev 10(2): 274-284.

BULATI M, BUFFA S, MARTORANA A, CANDORE G, LIO D, CARUSO C AND COLONNA-ROMANO G. 2014. Trafficking phenotype and production of granzyme B by double negative $\mathrm{B}$ cells $(\operatorname{IgG}(+) \operatorname{IgD}(-) \mathrm{CD} 27(-))$ in the elderly. Exp Gerontol 54(1): 123-129.

BULATI M, BUFFA S, MARTORANA A, GERVASI F, CAMARDA C, AZZARELLO DM, MONASTERO R, CARUSO C AND COLONNA-ROMANO G. 2015. Double negative (IgG+IgD-CD27-) B cells are increased in a cohort of moderate-severe Alzheimer's disease patients and show a pro-inflammatory trafficking receptor phenotype. J Alzheimers Dis 44(4): 1241-1251.

BURNS EA AND GOODWIN JS. 1997. Immunodeficiency of Aging. Drugs \& Aging 11(5): 374-397.

BUTCHER S, CHAHEL H AND LORD JM. 2000. Review article: ageing and the neutrophil: no appetite for killing? Immunology 100(4): 411-416.

CAMOUS X, PERA A, SOLANA R AND LARBI A. 2012. NK cells in healthy aging and age-associated diseases. $J$ Biomed Biotechnol 2012(2012): 195956.

CAMPISI J AND D'ADDA DI FAGAGNA F. 2007. Cellular senescence: when bad things happen to good cells. Nat Rev Mol Cell Biol 8(9): 729-740.
CAMPOS C, PERA A, LOPEZ-FERNANDEZ I, ALONSO C, TARAZONA R AND SOLANA R. 2014. Proinflammatory status influences NK cells subsets in the elderly. Immunol Lett 162(1): 298-302.

CAO JN, GOLLAPUDI S, SHARMAN EH, JIA Z AND GUPTA S. 2010. Age-related alterations of gene expression patterns in human CD8+ T cells. Aging Cell 9(1): 19-31.

CHEN MM, PALMER JL, PLACKETT TP, DEBURGHGRAEVE CR AND KOVACS EJ. 2014. Agerelated differences in the neutrophil response to pulmonary pseudomonas infection. Exp Gerontol 54(1): 42-46.

CHILDS BG, BAKER DJ, KIRKLAND JL, CAMPISI J AND VAN DEURSEN JM. 2014. Senescence and apoptosis: dueling or complementary cell fates? EMBO Rep 15(11): 1139-1153.

CHILOSI M ET AL. 2014. Oncogene-induced senescence distinguishes indolent from aggressive forms of pulmonary and non-pulmonary Langerhans cell histiocytosis. Leuk Lymphoma 55(11): 2620-2626.

CHIMENTI C ET AL. 2003. Senescence and death of primitive cells and myocytes lead to premature cardiac aging and heart failure. Circ Res 93(7): 604-613.

CHIU BC, MARTIN BE, STOLBERG VR AND CHENSUE SW. 2013. The host environment is responsible for agingrelated functional NK cell deficiency. J Immunol 191(9): 4688-4698.

CHOU JP AND EFFROS RB. 2013. T cell replicative senescence in human aging. Curr Pharm Des 19(9): 16801698.

CHOUGNET CA, THACKER RI, SHEHATA HM, HENNIES CM, LEHN MA, LAGES CS AND JANSSEN EM. 2015. Loss of Phagocytic and Antigen Cross-Presenting Capacity in Aging Dendritic Cells Is Associated with Mitochondrial Dysfunction. J Immunol 195(6): 2624-2632.

COLLADO M ET AL. 2005. Tumour biology: senescence in premalignant tumours. Nature 436(7051): 642.

COPPE JP, DESPREZ PY, KRTOLICA A AND CAMPISI J. 2010. The senescence-associated secretory phenotype: the dark side of tumor suppression. Annu Rev Pathol 5(1): 99-118.

CREPIN T ET AL. 2015. ATG-induced accelerated immune senescence: clinical implications in renal transplant recipients. Am J Transplant 15(4): 1028-1038.

DACE DS AND APTE RS. 2008. Effect of senescence on macrophage polarization and angiogenesis. Rejuvenation Res 11(1): 177-185.

DAVALOS AR, COPPE JP, CAMPISI J AND DESPREZ PY. 2010. Senescent cells as a source of inflammatory factors for tumor progression. Cancer Metastasis Rev 29(2): 273283.

DENSON LA. 2013. The role of the innate and adaptive immune system in pediatric inflammatory bowel disease. Inflamm Bowel Dis 19(9): 2011-2020. 
DERUY E, NASSOUR J, MARTIN N, VERCAMER C, MALAQUIN N, BERTOUT J, CHELLI F, POURTIER A, PLUQUET O AND ABBADIE C. 2014. Level of macroautophagy drives senescent keratinocytes into cell death or neoplastic evasion. Cell Death Dis 5(1): e1577.

DHEEN ST, KAUR C AND LING EA. 2007. Microglial activation and its implications in the brain diseases. Curr Med Chem 14(11): 1189-1197.

DIGGS J. 2008. Autoimmune Theory of Aging. In: Loue SJD and Sajatovic M (Eds), Encyclopedia of Aging and Public Health, Boston, MA: Springer US, p. 143-144.

DUNKELBERGER JR AND SONG WC. 2010. Complement and its role in innate and adaptive immune responses. Cell Res 20(1): 34-50.

DUNN-WALTERS DK, BANERJEE M AND MEHR R. 2003. Effects of age on antibody affinity maturation. Biochem Soc Trans 31(2): 447-448.

EBERSOLE JL AND STEFFEN MJ. 1989. Aging effects on secretory IgA immune responses. Immunol Invest 18(1-4): 59-68.

EFFROS RB, DAGARAG M, SPAULDING C AND MAN J. 2005. The role of CD8+ T-cell replicative senescence in human aging. Immunol Rev 205(1): 147-157.

ELPEK KG, RUBINSTEIN MP, BELLEMARE-PELLETIER A, GOLDRATH AW AND TURLEY SJ. 2010. Mature natural killer cells with phenotypic and functional alterations accumulate upon sustained stimulation with IL-15/IL-15Ralpha complexes. Proc Natl Acad Sci USA 107(50): 21647-21652.

FAGNONI FF, VESCOVINI R, PASSERI G, BOLOGNA G, PEDRAZZONI M, LAVAGETTO G, CASTI A, FRANCESCHI C, PASSERI M AND SANSONI P. 2000. Shortage of circulating naive $\mathrm{CD} 8(+) \mathrm{T}$ cells provides new insights on immunodeficiency in aging. Blood 95(9): 2860-2868.

FARAGE MA, MILLER KW, BERARDESCA E AND MAIBACH HI. 2009. Clinical implications of aging skin: cutaneous disorders in the elderly. Am J Clin Dermatol 10(2): 73-86.

FERRANDO-MARTINEZ S, RUIZ-MATEOS E, HERNANDEZ A, GUTIERREZ E, RODRIGUEZMENDEZ MM, ORDONEZ A AND LEAL M. 2011. Agerelated deregulation of naive $\mathrm{T}$ cell homeostasis in elderly humans. Age 33(2): 197-207.

FORTIN CF, LARBI A, DUPUIS G, LESUR O AND FULOP JR T. 2007. GM-CSF activates the Jak-STAT pathway to rescue polymorphonuclear neutrophils from spontaneous apoptosis in young but not elderly individuals. Biogerontology 8(2): 173-187.

FRANCESCHI C, BONAFE M AND VALENSIN S. 2000. Human immunosenescence: the prevailing of innate immunity, the failing of clonotypic immunity, and the filling of immunological space. Vaccine 18(16): 17171720 .
FRANCESCHI C ET AL. 2007. Inflammaging and antiinflammaging: a systemic perspective on aging and longevity emerged from studies in humans. Mech Ageing Dev 128(1): 92-105.

FREUND A, LABERGE RM, DEMARIA M AND CAMPISI J. 2012. Lamin B1 loss is a senescence-associated biomarker. Mol Biol Cell 23(11): 2066-2075.

FUCHS T ET AL. 2012. The neutrophil recombinatorial TCRlike immune receptor is expressed across the entire human life span but repertoire diversity declines in old age. Biochem Biophys Res Commun 419(2): 309-315.

FUENTES E, FUENTES F, VILAHUR G, BADIMON L AND PALOMO I. 2013. Mechanisms of chronic state of inflammation as mediators that link obese adipose tissue and metabolic syndrome. Mediators Inflamm 2013(2013): 136584.

FULOP T, FORIS G, WORUM I AND LEOVEY A. 1985. Age-dependent alterations of Fc gamma receptormediated effector functions of human polymorphonuclear leucocytes. Clin Exp Immunol 61(2): 425-432.

FULOP T, LE PAGE A, FORTIN C, WITKOWSKI JM, DUPUIS G AND LARBI A. 2014. Cellular signaling in the aging immune system. Curr Opin Immunol 29(1): 105111.

GARCIA GG AND MILLER RA. 2002. Age-dependent defects in TCR-triggered cytoskeletal rearrangement in CD4+ T cells. J Immunol 169(9): 5021-5027.

GAYOSO I, SANCHEZ-CORREA B, CAMPOS C, ALONSO C, PERA A, CASADO JG, MORGADO S, TARAZONA R AND SOLANA R. 2011. Immunosenescence of human natural killer cells. J Innate Immun 3(4): 337-343.

GITLIN AD AND NUSSENZWEIG MC. 2015. Immunology: Fifty years of B lymphocytes. Nature 517(7533): 139-141.

GOLOMB L, SAGIV A, PATERAS IS, MALY A, KRIZHANOVSKY V, GORGOULIS VG, OREN M AND BEN-YEHUDA A. 2015. Age-associated inflammation connects RAS-induced senescence to stem cell dysfunction and epidermal malignancy. Cell Death Differ 22(11): 1764-1774.

GRAEBER MB, LI W AND RODRIGUEZ ML. 2011. Role of microglia in CNS inflammation. FEBS Lett 585(23): 3798-3805.

GUAYERBAS N, CATALAN M, VICTOR VM, MIQUEL J AND DE LA FUENTE M. 2002. Relation of behaviour and macrophage function to life span in a murine model of premature immunosenescence. Behav Brain Res 134(1-2): 41-48.

GUPTA S. 2014. Role of dendritic cells in innate and adaptive immune response in human aging. Exp Gerontol 54(1): 47-52.

HARRIES LW ET AL. 2011. Human aging is characterized by focused changes in gene expression and deregulation of alternative splicing. Aging Cell 10(5): 868-878. 
HAYHOE RP, HENSON SM, AKBAR AN AND PALMER DB. 2010. Variation of human natural killer cell phenotypes with age: identification of a unique KLRG1-negative subset. Hum Immunol 71(7): 676-681.

HAZELDINE J, HARRIS P, CHAPPLE IL, GRANT M, GREENWOOD H, LIVESEY A, SAPEY E AND LORD JM. 2014. Impaired neutrophil extracellular trap formation: a novel defect in the innate immune system of aged individuals. Aging Cell 13(4): 690-698.

HAZELDINE J AND LORD JM. 2013. The impact of ageing on natural killer cell function and potential consequences for health in older adults. Ageing Res Rev 12(4): 10691078.

HENRY CJ, HUANG Y, WYNNE AM AND GODBOUT JP. 2009. Peripheral lipopolysaccharide (LPS) challenge promotes microglial hyperactivity in aged mice that is associated with exaggerated induction of both proinflammatory IL-1beta and anti-inflammatory IL-10 cytokines. Brain Behav Immun 23(3): 309-317.

HERRERO C, MARQUES L, LLOBERAS J AND CELADA A. 2001. IFN-gamma-dependent transcription of MHC class II IA is impaired in macrophages from aged mice. $\mathrm{J}$ Clin Invest 107(4): 485-493.

HERRERO C, SEBASTIAN C, MARQUES L, COMALADA M, XAUS J, VALLEDOR AF, LLOBERAS J AND CELADA A. 2002. Immunosenescence of macrophages: reduced MHC class II gene expression. Exp Gerontol 37(2-3): 389-394.

IWASAKI A AND MEDZHITOV R. 2015. Control of adaptive immunity by the innate immune system. Nat Immunol 16(4): 343-353.

JAFARZADEH A, SADEGHI M, KARAM GA AND VAZIRINEJAD R. 2010. Salivary IgA and IgE levels in healthy subjects: relation to age and gender. Braz Oral Res 24(1): 21-27.

JIANG M, XIANG Y, WANG D, GAO J, LIU D, LIU Y, LIU S AND ZHENG D. 2012. Dysregulated expression of miR-146a contributes to age-related dysfunction of macrophages. Aging Cell 11(1): 29-40.

JING H AND LEE S. 2014. NF-kappaB in cellular senescence and cancer treatment. Mol Cells 37(3): 189-195.

JOHNSON SA AND CAMBIER JC. 2004. Ageing, autoimmunity and arthritis: senescence of the B cell compartment - implications for humoral immunity. Arthritis Res Ther 6(4): 131-139.

KEREN Z, NAOR S, NUSSBAUM S, GOLAN K, ITKIN T, SASAKI Y, SCHMIDT-SUPPRIAN M, LAPIDOT T AND MELAMED D. 2011. B-cell depletion reactivates B lymphopoiesis in the $\mathrm{BM}$ and rejuvenates the $\mathrm{B}$ lineage in aging. Blood 117(11): 3104-3112.

KIM JA, PARK SK, KUMAR M, LEE CH AND SHIN OS. 2015. Insights into the role of immunosenescence during varicella zoster virus infection (shingles) in the aging cell model. Oncotarget 6(34): 35324-35343.
KIM SW, MO JH, KIM JW, KIM DY, RHEE CS, LEE CH AND MIN YG. 2007. Change of nasal function with aging in Korean. Acta Otolaryngol Suppl 558(1): 90-94.

KING PT, NGUI J, FARMER MW, HUTCHINSON P, HOLMES PW AND HOLDSWORTH SR. 2008. Cytotoxic T lymphocyte and natural killer cell responses to non-typeable Haemophilus influenzae. Clin Exp Immunol 152(3): 542-551.

KINN PM, HOLDREN GO, WESTERMEYER BA, ABUISSA M, FISCHER CL, FAIRLEY JA, BROGDEN KA AND BROGDEN NK. 2015. Age-dependent variation in cytokines, chemokines, and biologic analytes rinsed from the surface of healthy human skin. Sci Rep 5(1): 10472.

KIZAKI T, SUZUKI K, OOKAWARA T, IZAWA T, SAITOH D, OH-ISHI S, HAGA S AND OHNO H. 2002. Stress- and aging-associated modulation of macrophage functions. Environ Health Prev Med 6(4): 218-228.

KOJIMA H, INOUE T, KUNIMOTO H AND NAKAJIMA K. 2013. IL-6-STAT3 signaling and premature senescence. Jak-Stat 2(4): e25763.

KOLLAR S, BERTA L, VASARHELYI ZE, BALOG A, VASARHELYI B, RIGO JR T AND TOLDI G. 2015. Impact of aging on calcium influx and potassium channel characteristics of $\mathrm{T}$ lymphocytes. Oncotarget 6(15): 13750-13756.

KOTTNER J, LICHTERFELD A AND BLUME-PEYTAVI U. 2013. Maintaining skin integrity in the aged: a systematic review. Br J Dermatol 169(3): 528-542.

KRISHNARAJ R. 1997. Senescence and cytokines modulate the NK cell expression. Mech Ageing Dev 96: 89-101.

KUNKEL SL, STANDIFORD T, KASAHARA K AND STRIETER RM. 1991. Interleukin-8 (IL-8): the major neutrophil chemotactic factor in the lung. Exp Lung Res 17(1): 17-23.

KUWAHARA M ET AL. 2014. The Menin-Bach2 axis is critical for regulating CD4 T-cell senescence and cytokine homeostasis. Nat Commun 5(1): 3555.

LENARDO M, CHAN KM, HORNUNG F, MCFARLAND H, SIEGEL R, WANG J AND ZHENG L. 1999. Mature $\mathrm{T}$ lymphocyte apoptosis-immune regulation in a dynamic and unpredictable antigenic environment. Annu Rev Immunol 17(1): 221-253.

LI G, YU M, LEE WW, TSANG M, KRISHNAN E, WEYAND CM AND GORONZY JJ. 2012. Decline in miR-181a expression with age impairs $\mathrm{T}$ cell receptor sensitivity by increasing DUSP6 activity. Nat Med 18(10): 1518-1524.

LI QJ ET AL. 2007. miR-181a is an intrinsic modulator of T cell sensitivity and selection. Cell 129(1): 147-161.

LIU D, WANG D, XU Z, GAO J, LIU M, LIU Y, JIANG M AND ZHENG D. 2015. Dysregulated expression of miR$101 \mathrm{~b}$ and miR-26b lead to age-associated increase in LPSinduced COX-2 expression in murine macrophage. Age 37(5): 97. 
LIU WM, NAHAR TE, JACOBI RH, GIJZEN K, VAN BEEK J, HAK E, JONGES M, BOOG CJ, VAN DER ZEIJST BA AND SOETHOUT EC. 2012. Impaired production of TNF-alpha by dendritic cells of older adults leads to a lower CD8+ T cell response against influenza. Vaccine 30(9): 1659-1666.

LULL ME AND BLOCK ML. 2010. Microglial activation and chronic neurodegeneration. Neurotherapeutics 7(4): 354-365.

LUTZ CT AND QUINN LS. 2012. Sarcopenia, obesity, and natural killer cell immune senescence in aging: altered cytokine levels as a common mechanism. Aging (Albany NY) 4(8): 535-546.

MAHBUB S, DEBURGHGRAEVE CR AND KOVACS EJ. 2012. Advanced age impairs macrophage polarization. J Interferon Cytokine Res 32(1): 18-26.

MANESTAR-BLAZIC T AND VOLF M. 2009. The dynamic of senescent cells accumulation can explain the age-specific incidence of autoimmune diseases. Med Hypotheses 73(5): 667-669.

MARIANI E, MENEGHETTI A, NERI S, RAVAGLIA G, FORTI P, CATTINI L AND FACCHINI A. 2002. Chemokine production by natural killer cells from nonagenarians. Eur J Immunol 32(6): 1524-1529.

MARTINET KZ, BLOQUET S AND BOURGEOIS C. 2014. Ageing combines CD4 T cell lymphopenia in secondary lymphoid organs and $\mathrm{T}$ cell accumulation in gut associated lymphoid tissue. Immun Ageing 11(1): 1-8.

MARTORANA A, BALISTRERI CR, BULATI M, BUFFA S, AZZARELLO DM, CAMARDA C, MONASTERO R, CARUSO C AND COLONNA-ROMANO G. 2014. Double negative (CD19+IgG+IgD-CD27-) B lymphocytes: a new insight from telomerase in healthy elderly, in centenarian offspring and in Alzheimer's disease patients. Immunol Lett 162(1): 303-309.

MCELHANEY JE AND EFFROS RB. 2009. Immunosenescence: what does it mean to health outcomes in older adults? Curr Opin Immunol 21(4): 418-424.

MOCCHEGIANI E, GIACCONI R, CIPRIANO C AND MALAVOLTA M. 2009. NK and NKT cells in aging and longevity: role of zinc and metallothioneins. J Clin Immunol 29(4): 416-425.

MONDALAM ET AL. 2013. p53 isoforms regulate aging- and tumor-associated replicative senescence in T lymphocytes. J Clin Immunol 123(12): 5247-5257.

MONTGOMERY RR AND SHAW AC. 2015. Paradoxical changes in innate immunity in aging: recent progress and new directions. J Leukoc Biol 98(6): 937-943.

MONTOYA-ORTIZ G. 2013. Immunosenescence, aging, and systemic lupus erythematous. Autoimmune Dis 2013(2013): 267078 .

MORETTO MM, LAWLOR EM AND KHAN IA. 2008. Aging mice exhibit a functional defect in mucosal dendritic cell response against an intracellular pathogen. J Immunol 181(11): 7977-7984.

MORO-GARCIA MA, ALONSO-ARIAS R AND LOPEZLARREA C. 2012. Molecular mechanisms involved in the aging of the T-cell immune response. Curr Genomics 13(8): 589-602.

MORO-GARCIA MA ET AL. 2014. Immunosenescence and inflammation characterize chronic heart failure patients with more advanced disease. Int J Cardiol 174(3): 590599.

NG TP, CAMOUS X, NYUNT MSZ, VASUDEV A, TAN CTY, FENG L, FULOP T, YAP KB AND LARBI A. 2015. Markers of T-cell senescence and physical frailty: insights from Singapore Longitudinal Ageing Studies. Npj Aging Mechan Dis 1(1): 15005.

NORDEN DM AND GODBOUT JP. 2013. Review: microglia of the aged brain: primed to be activated and resistant to regulation. Neuropathol Appl Neurobiol 39(1): 19-34.

ODDEN MC, COXSON PG, MORAN A, LIGHTWOOD JM, GOLDMAN L AND BIBBINS-DOMINGO K. 2011. The impact of the aging population on coronary heart disease in the United States. Am J Med 124(9): 827-833.

ONYEMA OO, DECOSTER L, NJEMINI R, FORTI LN, BAUTMANS I, DE WAELE M AND METS T. 2015. Chemotherapy-induced changes and immunosenescence of CD8+ T-cells in patients with breast cancer. Anticancer Res 35(3): 1481-1489.

ORTEGA E, GARCIA JJ AND DE LA FUENTE M. 2000. Modulation of adherence and chemotaxis of macrophages by norepinephrine. Influence of ageing. Mol Cell Biochem 203(1-2): 113-117.

PALMER DB. 2013. The effect of age on thymic function. Front Immunol 4(316): 1-6.

PANDA A ET AL. 2010. Age-associated decrease in TLR function in primary human dendritic cells predicts influenza vaccine response. J Immunol 184(7): 2518-2527.

PARISH ST, WU JE AND EFFROS RB. 2009. Modulation of $\mathrm{T}$ lymphocyte replicative senescence via TNF- $\{$ alpha $\}$ inhibition: role of caspase-3. J Immunol 182(7): 4237-4243.

PERRY VH AND HOLMES C. 2014. Microglial priming in neurodegenerative disease. Nat Rev Neurol 10(4): $217-$ 224.

PERRY VH AND TEELING J. 2013. Microglia and macrophages of the central nervous system: the contribution of microglia priming and systemic inflammation to chronic neurodegeneration. Semin Immunopathol 35(5): 601-612.

PIETILÄ M, NEUVONEN M, BORODULIN K, KORPELA K, SIEVÄNEN T AND TYRVÄINEN L. 2015. Relationships between exposure to urban green spaces, physical activity and self-rated health. J Outdoor Recr Tou 10(1): 44-54.

POLAND GA, OVSYANNIKOVA IG, KENNEDY RB, LAMBERT ND AND KIRKLAND JL. 2014. A systems 
biology approach to the effect of aging, immunosenescence and vaccine response. Curr Opin Immunol 29(1): 62-68.

PRAKASH S, AGRAWAL S, CAO JN, GUPTA S AND AGRAWAL A. 2013. Impaired secretion of interferons by dendritic cells from aged subjects to influenza : role of histone modifications. Age 35(5): 1785-1797.

PRELOG M. 2006. Aging of the immune system: a risk factor for autoimmunity? Autoimmun Rev 5(2): 136-139.

PRITZ T, LAIR J, BAN M, KELLER M, WEINBERGER B, KRISMER M AND GRUBECK-LOEBENSTEIN B. 2015. Plasma cell numbers decrease in bone marrow of old patients. Eur J Immunol 45(3): 738-746.

RAINHAM DG, BATES CJ, BLANCHARD CM, DUMMER TJ, KIRK SF AND SHEARER CL. 2012. Spatial Classification of Youth Physical Activity Patterns. Am J Prev Med 42(5): e87-e96.

RAJAGOPALAN S AND LONG EO. 2012. Cellular senescence induced by CD158d reprograms natural killer cells to promote vascular remodeling. Proc Natl Acad Sci USA 109(50): 20596-20601.

ROSENBERG C, BOVIN NV, BRAM LV, FLYVBJERG E, ERLANDSEN M, VORUP-JENSEN T AND PETERSEN E. 2013. Age is an important determinant in humoral and $\mathrm{T}$ cell responses to immunization with hepatitis B surface antigen. Hum Vaccin Immunother 9(7): 1466-1476.

ROSENSTIEL P, DERER S, TILL A, HASLER R, EBERSTEIN H, BEWIG B, NIKOLAUS S, NEBEL A AND SCHREIBER S. 2008. Systematic expression profiling of innate immune genes defines a complex pattern of immunosenescence in peripheral and intestinal leukocytes. Genes Immun 9(2): 103-114.

SAPEY E, GREENWOOD H, WALTON G, MANN E, LOVE A, AARONSON N, INSALL RH, STOCKLEY RA AND LORD JM. 2014. Phosphoinositide 3-kinase inhibition restores neutrophil accuracy in the elderly: toward targeted treatments for immunosenescence. Blood 123(2): 239-248.

SARDI F, FASSINA L, VENTURINI L, INGUSCIO M, GUERRIERO F, ROLFO E AND RICEVUTI G. 2011. Alzheimer's disease, autoimmunity and inflammation. The good, the bad and the ugly. Autoimmun Rev 11(2): 149153.

SCHENTEN D AND MEDZHITOV R. 2011. The control of adaptive immune responses by the innate immune system. Adv Immunol 109(1): 87-124.

SCHMITT V, RINK L AND UCIECHOWSKI P. 2013. The Th17/Treg balance is disturbed during aging. Exp Gerontol 48(12): 1379-1386.

SEBASTIAN C, HERRERO C, SERRA M, LLOBERAS J, BLASCO MA AND CELADA A. 2009. Telomere shortening and oxidative stress in aged macrophages results in impaired STAT5a phosphorylation. J Immunol 183(4): 2356-2364.

SHARMA R, KAPILA R, HAQ MR, SALINGATI V, KAPASIYA M AND KAPILA S. 2014. Age-associated aberrations in mouse cellular and humoral immune responses. Aging Clin Exp Res 26(4): 353-362.

SHAW AC, PANDA A, JOSHI SR, QIAN F, ALLORE HG AND MONTGOMERY RR. 2011. Dysregulation of human Toll-like receptor function in aging. Ageing Res Rev 10(3): 346-353.

SHEHATA HM, HOEBE K AND CHOUGNET CA. 2015. The aged nonhematopoietic environment impairs natural killer cell maturation and function. Aging Cell 14(2): 191199.

SHI C AND PAMER EG. 2011. Monocyte recruitment during infection and inflammation. Nat Rev Immunol 11(11): 762-774.

SICA A, MATSUSHIMA K, VAN DAMME J, WANG JM, POLENTARUTTI N, DEJANA E, COLOTTA F AND MANTOVANI A. 1990. IL-1 transcriptionally activates the neutrophil chemotactic factor/IL-8 gene in endothelial cells. Immunology 69(4): 548-553.

SIKORA E. 2015. Activation-induced and damage-induced cell death in aging human T cells. Mech Ageing Dev 151(1): 85-92.

SMITH DJ, TAUBMAN MA AND EBERSOLE JL. 1987. Ontogeny and senescence of salivary immunity. J Dent Res 66(2): 451-456.

SOLANA R, CAMPOS C, PERA A AND TARAZONA R. 2014. Shaping of NK cell subsets by aging. Curr Opin Immunol 29(1): 56-61.

SOLANA R, TARAZONA R, GAYOSO I, LESUR O, DUPUIS G AND FULOP T. 2012. Innate immunosenescence: effect of aging on cells and receptors of the innate immune system in humans. Semin Immunol 24(5): 331-341.

SRIDHARAN A, ESPOSO M, KAUSHAL K, TAY J, OSANN K, AGRAWAL S, GUPTA S AND AGRAWAL A. 2011. Age-associated impaired plasmacytoid dendritic cell functions lead to decreased CD4 and CD8 T cell immunity. Age 33(3): 363-376.

STERVBO U ET AL. 2015. Effects of aging on human leukocytes (part II): immunophenotyping of adaptive immune B and T cell subsets. Age 37(5): 93.

STOUT-DELGADO HW, YANG X, WALKER WE, TESAR BM AND GOLDSTEIN DR. 2008. Aging impairs IFN regulatory factor 7 up-regulation in plasmacytoid dendritic cells during TLR9 activation. J Immunol 181(10): $6747-$ 6756.

STRANKS AJ ET AL. 2015. Autophagy Controls Acquisition of Aging Features in Macrophages. J Innate Immun 7(4): 375-391.

SUCHY D, LABUZEK K, BULDAK L, SZKUDLAPSKI D AND OKOPIEN B. 2014. Comparison of chosen activation markers of human monocytes/macrophages isolated from the peripheral blood of young and elderly volunteers. Pharmacol Rep 66(5): 759-765.

SUMMERS C, RANKIN SM, CONDLIFFE AM, SINGH N, PETERS AM AND CHILVERS ER. 2010. Neutrophil 
kinetics in health and disease. Trends Immunol 31(8): 318 324.

TEDDER TF, TUSCANO J, SATO S AND KEHRL JH. 1997. CD22, a B lymphocyte-specific adhesion molecule that regulates antigen receptor signaling. Annu Rev Immunol 15(1): 481-504.

TESAR BM, WALKER WE, UNTERNAEHRER J, JOSHI NS, CHANDELE A, HAYNES L, KAECH S AND GOLDSTEIN DR. 2006. Murine [corrected] myeloid dendritic cell-dependent toll-like receptor immunity is preserved with aging. Aging Cell 5(6): 473-486.

TORELLA D ET AL. 2004. Cardiac stem cell and myocyte aging, heart failure, and insulin-like growth factor-1 overexpression. Circ Res 94(4): 514-524.

VALLEJO AN. 2005. CD28 extinction in human T cells: altered functions and the program of T-cell senescence. Immunol Rev 205(1): 158-169.

VAN DEURSEN JM. 2014. The role of senescent cells in ageing. Nature 509(7501): 439-446.

VAN DUIN D, ALLORE HG, MOHANTY S, GINTER S, NEWMAN FK, BELSHE RB, MEDZHITOV R AND SHAW AC. 2007a. Prevaccine determination of the expression of costimulatory B7 molecules in activated monocytes predicts influenza vaccine responses in young and older adults. J Infect Dis 195(11): 1590-1597.

VAN DUIN D, MOHANTY S, THOMAS V, GINTER S, MONTGOMERY RR, FIKRIG E, ALLORE HG, MEDZHITOV R AND SHAW AC. 2007b. Age-associated defect in human TLR-1/2 function. J Immunol 178(2): 970-975.

VASUDEV A ET AL. 2014. gamma/delta T cell subsets in human aging using the classical alpha/beta T cell model. J Leukoc Biol 96(4): 647-655.

VESELY MD, KERSHAW MH, SCHREIBER RD AND SMYTH MJ. 2011. Natural innate and adaptive immunity to cancer. Annu Rev Immunol 29(1): 235-271.
VILLANUEVA JL, SOLANA R, ALONSO MC AND PENA J. 1990. Changes in the expression of HLA-class II antigens on peripheral blood monocytes from aged humans. Dis Markers 8(2): 85-91.

VISENTINI M ET AL. 2011. Telomere-dependent replicative senescence of $\mathrm{B}$ and $\mathrm{T}$ cells from patients with type 1a common variable immunodeficiency. Eur J Immunol 41(3): 854-862.

VIVIER E, TOMASELLO E, BARATIN M, WALZER T AND UGOLINI S. 2008. Functions of natural killer cells. Nat Immunol 9(5): 503-510.

WALFORD R. 1969. The immunologic theory of aging. The University of Michigan, p. 1-248.

WARRINGTON KJ, VALLEJO AN, WEYAND CM AND GORONZY JJ. 2003. CD28 loss in senescent CD4+ T cells: reversal by interleukin-12 stimulation. Blood 101(9): 3543-3549.

WEISKOPF D, WEINBERGER B AND GRUBECKLOEBENSTEIN B. 2009. The aging of the immune system. Transpl Int 22(11): 1041-1050.

WEKSLER ME. 2000. Changes in the B-cell repertoire with age. Vaccine 18(16): 1624-1628.

WEYAND CM, YANG Z AND GORONZY JJ. 2014. T-cell aging in rheumatoid arthritis. Curr Opin Rheumatol 26(1): 93-100.

WONG C AND GOLDSTEIN DR. 2013. Impact of aging on antigen presentation cell function of dendritic cells. Curr Opin Immunol 25(4): 535-541.

ZACCA ER, CRESPO MI, ACLAND RP, ROSELLI E, NUNEZ NG, MACCIONI M, MALETTO BA, PISTORESI-PALENCIA MC AND MORON G. 2015. Aging Impairs the Ability of Conventional Dendritic Cells to Cross-Prime CD8+ T Cells upon Stimulation with a TLR7 Ligand. PloS ONE 10(10): e0140672.

ZAWROTNIAK M AND RAPALA-KOZIK M. 2013. Neutrophil extracellular traps (NETs) - formation and implications. Acta Biochim Pol 60(3): 277-284. 
